\title{
The Differences in Body Image in terms of Gender, Cultural Background, and Students Admission Path
}

\author{
Verlanda Yuca ${ }^{*}$, Triave Nuzila Zahri ${ }^{2}$, Elrisfa Magistarina ${ }^{3}$ \\ 1,2,3 Universitas Negeri Padang \\ *Corresponding author, e-mail: verlanda@konselor.org
}

\begin{abstract}
As a part of physiological needs, human physical appearance is considered an essential part of people's lives. That integral part determines the formation of body image in the community. Body image is a mental picture of the body state. The development of student body image is not wellformed, so that it affects their life. In the lecture process, students tend to be inactive and have low self-esteem, which impact student life. Some factors that affect the body image are gender, cultural background, and the admission way. This study aims to describe the body image in terms of gender, cultural background, student's admission way, and the group's interaction. This study used a descriptive comparative method with 600 samples - the data collection using Yuca Puji Body-Image Inventory (YPBI) and ANOVA as an analyzing tool. The result shows significant differences in body image in terms of gender, cultural background, and admission. The results of this research can prove that student can develop body image in a positive direction. This result of the study will be used as a basic concept to determine a body image module.
\end{abstract}

Keywords: Body Image; Gender; Cultural Background; Student's admission way

How to Cite: Yuca, V., Zahri, T.N., \& Magistarina, E. (2021). The Differences in Body Image in terms of Gender, Cultural Background, and Students Admission Path. International Journal of Research in Counseling and Education, 4 (2): pp. 135-141, DOI:http://doi.org/10.24036/00403za0002

This is an open access article distributed under the Creative Commons 4.0 Attribution License, which permits unrestricted use distribution, and reproduction in any medium, provided the original work is properly cited. @2020 by Author.

\section{Introduction}

A finding initiated from previous research reveals a picture of the body image of students at Padang State University, in which it showed an overall view of the level of body image of students in 2019, which on average was high (78.35\%) (Yuca \& Handayani, 2019). The body image depicted is an aspect of a person's psychological and interpersonal development that can affect adolescent self-esteem in general (Cash, 2002; Cash \& Pruzinsky, 2002; Chaplin \& John, 2010; Orth \& Robins, 2014).

Body Image is an aspect related of psychological development and interpersonal relationships in adolescents (students) (Denich \& Ifdil, 2015). Display orientation, both men and women pay more attention to appearance, especially the physical body, compared to other aspects of human life (Gunarsa, 1991; Winarni, 2015; Perloff, 2014). One of the developments in body image that a person forms is related to gender; There are differences in body image between men and women.

A positive body image will make adolescents feel comfortable with their body condition and have higher self-confidence in social relationships with other people. The development of negative body image result from various factors, including body mass, social comparisons, and conversations about appearance with peers (Fortman, 2006; Perloff, 2014). The development of negative body image results in adolescents'dissatisfaction with their physical condition and is correlated with low self-esteem, resulting in decreased self-confidence in adolescents. Furthermore, viewed from gender, body image can also be formed from local environmental conditions/traditions, particularlyin a local culture and how other people value the body they have (Hurlock, 1978; Hurlock, 2001; Comaroff, 2013). In addition, someone's acceptance of a specific environment also affects body image.

The development of body image that occurs to everyone is usually different (Wertheim \& Paxton, 2011; Tylka, 2018). This difference can be seen in the higher education environment, which reveals the difference in 
body image between students who enter the SBMPTN, SNMPTN, and Mandiri (Yuca \& Handayani, 2019; Paxton \& Damiano, 2017). Students who enter the SBMPTN have higherbody imagesthanthose who take other entry paths. This difference occurredsince the SBMPTN entry route is for students who passwritten examination passing scorewhich is held simultaneously by all state universities in Indonesia. On the other hand, the selection for admission to the SBMPTN usesstudents' high school report cards and the Independent Track students are selected and carried out by having writing testsat college. Based on the background problems above, results of this study will be described in further detail. The research study is related to the description of the student body image and differences in terms of gender, cultural background, and entry paths of students at the State University of Padang.

\section{Method}

\section{Participants}

The research population was all Padang State University year 2017 students from all faculties. Samples were taken by considering the science groups of each faculty using Simple Random Sampling. The total sample size was 600 respondents, with 75 respondents in each faculty.

\section{Measurement}

The stated product characteristics required an assessment instrument to reveal the data in this study. The instrument used Yuca Puji Body-Image Inventory (YPBI) was made from 2019 with a total of 42 items. Weighing the experts and testing several respondents, the total was 36 itemswas a Likert scale model questionnaire about body image.

\section{Data Analysis}

Data analysis used a comparative descriptive statistical approach. it is necessary to do it using a different test analysis using the SPSS data processing program version 20 to find out more about the results of the assessment with regard to the research product being developed.

\section{Results and Discussion}

The body image of UNP students is on average in the high category. This section will describe the differences in body image of UNP students in some perspectives: gender; Men and women, cultural backgrounds; Minang and Non-Minang, and the admission way to enter theuniversity; SBMPTN, SMNPTN, Mandiri.

a. Body image from Gender Perspective

Based on the data collected, there is an overview of the body image of UNP students, both male and female. The percentage description of the number of male and female respondents can be seen in Graph 1 below.

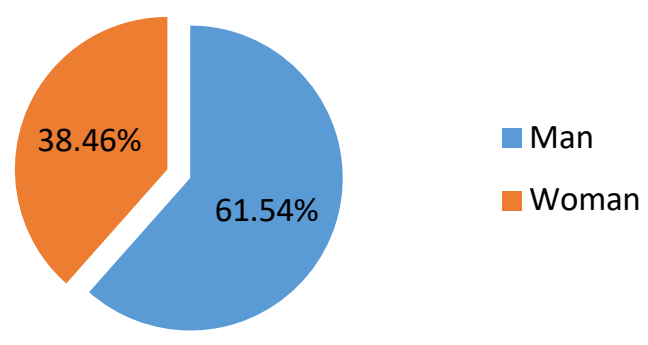

Graph 1. Overview of the Number of Respondents in terms of Gender

Graph 1 shows the number of male and female respondents, in which more than $60 \%$ of the percentage is male students . Furthermore, based on the percentage of the number of students above, the differences in student body image in terms of gender will be examined which can be seen in the following table. 
Table 1. Test Results for Body Image Differences in terms of Gender

\begin{tabular}{|c|c|c|c|c|c|c|c|c|c|c|}
\hline & & \multicolumn{2}{|c|}{$\begin{array}{c}\text { Levene's Test for } \\
\text { Equality of } \\
\text { Variances } \\
\end{array}$} & \multicolumn{7}{|c|}{$\mathrm{t}$-test for Equality of Means } \\
\hline & & \multirow[t]{2}{*}{$\mathrm{F}$} & \multirow[t]{2}{*}{ Sig. } & \multirow[t]{2}{*}{$\mathrm{T}$} & \multirow[t]{2}{*}{$\mathrm{df}$} & \multirow[t]{2}{*}{$\begin{array}{l}\text { Sig. (2- } \\
\text { tailed) }\end{array}$} & \multirow[t]{2}{*}{$\begin{array}{c}\text { Mean } \\
\text { Difference }\end{array}$} & \multirow[t]{2}{*}{$\begin{array}{l}\text { Std. Error } \\
\text { Difference }\end{array}$} & \multicolumn{2}{|c|}{$\begin{array}{c}\text { 95\% Confidence } \\
\text { Interval of the } \\
\text { Difference }\end{array}$} \\
\hline & & & & & & & & & Lower & Upper \\
\hline \multirow[t]{2}{*}{$\begin{array}{l}\text { Body } \\
\text { Image }\end{array}$} & $\begin{array}{l}\text { Equal } \\
\text { variances } \\
\text { assumed }\end{array}$ & 2.381 & .123 & 5.663 & 505 & .000 & 10.244 & 1.809 & 6.690 & 13.797 \\
\hline & $\begin{array}{l}\text { Equal } \\
\text { variances } \\
\text { not } \\
\text { assumed }\end{array}$ & & & 5.509 & 375.170 & .000 & 10.244 & 1.859 & 6.588 & 13.900 \\
\hline
\end{tabular}

Based on Table 1 above, with a significance of 0.000 , which means that it is small from the significance level of 0.05 , there is a significant difference in student body image between men and women. These results reveal that men have a higher body image than women.

b. Body image from cultural background perspective

Furthermore, the percentage description of the number of respondents in terms of cultural backgrounds; Minang and non-Minang can be seen in Graph 2 below.

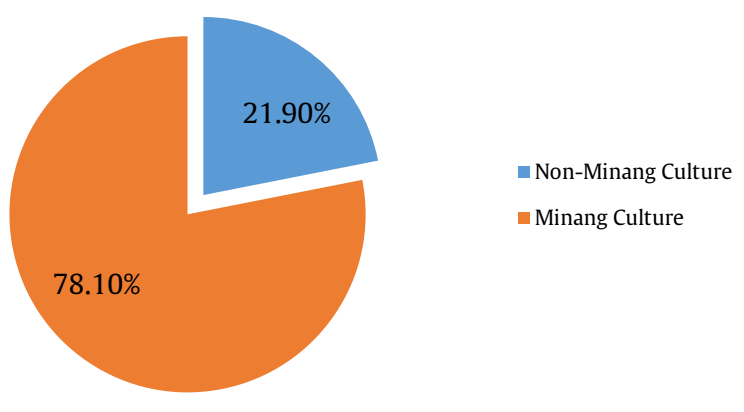

Graph 2. Overview of the Number of Respondents in terms of Cultural Background

Graph 2 shows the number of respondents between Minang and non-Minang cultural backgrounds, more than $75 \%$ of students comes from Minang backgrounds compared to students coming fromnon-Minang cultural backgrounds. Furthermore, based on the percentage of the number of students above, the differences in student body image will be examined in terms of cultural backgrounds which can be seen in the following table.

Table 2. Testing Results of Body Image Differences in terms of Cultural Background

\begin{tabular}{|c|c|c|c|c|c|c|c|c|c|c|}
\hline & & \multicolumn{3}{|c|}{$\begin{array}{c}\text { Levene's Test for } \\
\text { Equality of } \\
\text { Variances }\end{array}$} & \multicolumn{4}{|c|}{ t-test for Equality of Means } & & \\
\hline & & \multirow[t]{2}{*}{$\mathrm{F}$} & \multirow[t]{2}{*}{ Sig. } & \multirow[t]{2}{*}{$\mathrm{t}$} & \multirow[t]{2}{*}{ df } & \multirow[t]{2}{*}{$\begin{array}{l}\text { Sig. (2- } \\
\text { tailed) }\end{array}$} & \multirow[t]{2}{*}{$\begin{array}{c}\text { Mean } \\
\text { Difference }\end{array}$} & \multirow[t]{2}{*}{$\begin{array}{l}\text { Std. Error } \\
\text { Difference }\end{array}$} & \multicolumn{2}{|c|}{$\begin{array}{l}\text { 95\% Confidence } \\
\text { Interval of the } \\
\text { Difference }\end{array}$} \\
\hline & & & & & & & & & Lower & Upper \\
\hline \multirow[t]{2}{*}{$\begin{array}{l}\text { Body } \\
\text { Image }\end{array}$} & $\begin{array}{l}\text { Equal } \\
\text { variances } \\
\text { assumed }\end{array}$ & 1.581 & .209 & .370 & 505 & .711 & .812 & 2.194 & -3.499 & 5.123 \\
\hline & $\begin{array}{l}\text { Equal } \\
\text { variances } \\
\text { not } \\
\text { assumed }\end{array}$ & & & .340 & 158.072 & .735 & .812 & 2.393 & -3.913 & 5.538 \\
\hline
\end{tabular}


Based on Table 2 above, with a significance of 0.711 , the size of the 0.05 significance level means that there is no significant difference instudents' body image from Minang and non-Minang backgrounds. These results reveal that the student body image is not influenced by cultural backgrounds, either Minang culture or Non-Minang culture.

c. Body image from Admission way to the university perspective

Furthermore, the percentage description of the number of respondents in terms of tertiary entry pathways; SBMPTN, SNMPTN, and Mandiri can be seen in Graph 2 below.

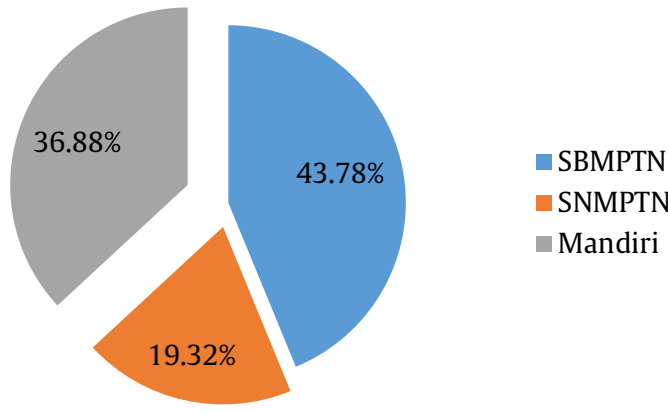

Graph 3. Overview of the Number of Respondents in terms ofPathway to College Entry

Graph 3 shows the number of respondents between the SBMPTN, SNMPTN, and Independent pathways, more than $40 \%$ of the number of students are who enter the SBMPTN route. Furthermore, based on the percentage above, the differences in student body image will be examined in terms of tertiary entry pathways which can be seen in the following table.

Table 3.Test Results for Body Image Differences in terms of Pathways to College Entry High

\begin{tabular}{lccccc}
\hline & $\begin{array}{c}\text { Sum of } \\
\text { Squares }\end{array}$ & df & $\begin{array}{c}\text { Mean } \\
\text { Square }\end{array}$ & F & Sig. \\
\hline $\begin{array}{l}\text { Between } \\
\text { Groups }\end{array}$ & 656.715 & 2 & 328.357 & .787 & .456 \\
$\begin{array}{l}\text { Within } \\
\text { Groups }\end{array}$ & 210200.611 & 504 & 417.065 & & \\
Total & 210857.325 & 506 & & & \\
\hline
\end{tabular}

Based on Table 3 above, with a significance of 0.456 , the size of 0.05 significance level means that there is no significant difference in student body image in terms of tertiary entry pathways through SBMPTN, SNMPTN, or Mandiri. These results reveal that students who enter the SBMPTN pathway have a higher body image than students who enter the SNMPTN and Independent pathways.

\section{Discussion}

Based on the findings above, body image in three perspectives, namely gender, cultural background, and pathway to college, have significant differences in gender aspect only. Body image in cultural background and pathways to higher education viewpoint donot have significant differences.

The main aspect of self-concept is body image, which is an individual's awareness and acceptance. Body image development depends on social relationships and is a long and often unpleasant process because projectedbody image is not always positive. Many things influence a person's body image development. The factors that influence the development of body image are gender, age, mass media, family, and interpersonal.

Gender is the most crucial factor in developing a person's body image(Nourmalita, 2016; MacNeill, Best, \& Davis, 2017; Gattario \& Frisén, 2019). Some studies done state that women view body image more negatively 
than men(Brown, Cash, \& Lewis, 1989; Cash \&Brown, 1989; Davison \& McCabe, 2006; Demarest \& Allen, 2000; Hubley \& Quinlan, 2005; Rozin \& Fallon, 1988; Cameron, Ward, Mandville-Anstey, \& Coombs, 2019). Men want to lookmasculinebecause they want to be moreconfident in front of their friends and follow the current trend. Meanwhile, women want to have an ideal and thin body to attract the attention of their environment. The efforts made by men to make the body more muscular are influenced by images in the mass media showing a male model who is muscular and muscular. Meanwhile, women tend to lose weight due to articles in women's magazines which often make promotional articles about weight loss(Andersen \& DiDomenico, 1992; Bassett-Gunter, McEwan, \& Kamarhie, 2017)

The next factor that influences the development of body image is age (Riaz, 2018). At the stage of adolescent development, body image becomes important (Papalia, Olds, \& Feldman, 2003). This play role on teenagers' excessive effort to control weight, which happens a lot in girlsthan boys. One of the psychological aspects of physical changes at puberty is that adolescents pay great attention to their bodies and build their own image of how their bodies look like(Santrock, 2007; Ahadzadeh, Sharif, \& Ong, 2017). Unstable physical and emotional changes often lead to body image dissatisfaction among young women. According to Erik Erikson's (1963) theory of developmental phases, adolescence enters the Identity vs Identity Confusion phase which begins at puberty and ends at the age of 18 or 20 years (Nelson, Kling, Wängqvist, Frisén, \& Syed, 2018; Crocetti, 2018).

Adolescents experience significant physical changes in their bodies during puberty, so that when their late teens experience different perceptions of their respective body image(Croll, 2005). Body Image itself is a multidimensional construct that reflects how individuals think, feel and behave about individual physical attributes(Cash, 2002; Cash \& Pruzinsky, 2002; Irvine, McCarty, McKenzie, Pollet, Cornelissen, Toveé, \& Cornelissen, 2019).

Furthermore, body image, which is viewed from a cultural background, follow the study results, which did not find a significant difference between students with Minang and non-Minang backgrounds. In theory, sociocultural is also a component in the development of a person's body image. Factors that influence body image include (1) other people's reactions, (2) comparison with other people and cultural ideas, (3) identification of other people, and (4) sociocultural factors.

Several theories and research results have revealed that social and cultural factors have a strong influence in shaping, developing, and maintaining body image problems in society. The sociocultural theory states that society determines what is beautiful and attractive according social standard of the society (Thompson \& Heinberg, 1999). cultural norms have a role in influencing the development of behavior and attitudes related to body image.

\section{References}

Ahadzadeh, A. S., Sharif, S. P., \& Ong, F. S. (2017). Self-schema and self-discrepancy mediate the influence of Instagram usage on body image satisfaction among youth. Computers in Human Behavior, 68, 8-16.

Andersen, A. E., \& DiDomenico, L. (1992). Diet vs. shape content of popular male and female magazines: A dose-response relationship to the incidence of eating disorders? International Journal of Eating Disorders, 11(3), 283-287.

Bassett-Gunter, R., McEwan, D., \& Kamarhie, A. (2017). Physical activity and body image among men and boys: A meta-analysis. Body Image, 22, 114-128.

Brown, T. A., Cash, T. F., \& Lewis, R. J. (1989). Body-Image Disturbances in Adolescent Female Binge-Purgers: A Brief Report of the Results of a National Survey in the USA. Journal of Child Psychology and Psychiatry, 30(4), 605-613.

Cameron, E., Ward, P., Mandville-Anstey, S. A., \& Coombs, A. (2019). The female aging body: A systematic review of female perspectives on aging, health, and body image. Journal of women \& aging, 31(1), 3-17.

Cash, T. F. (2002). The situational inventory of body-image dysphoria: Psychometric evidence and development of a short form. International Journal of Eating Disorders, 32(3), 362-366.

Cash, T. F., \& Brown, T. A. (1989). Gender and body images: Stereotypes and realities. Sex Roles, 21(5-6), 361373.

Cash, T. F., \& Pruzinsky, T. (2002). Future challenges for body image theory, research, and clinical practice. Body Image: A Handbook of Theory, Research, and Clinical Practice, 509-516. 
Chaplin, L. N., \& John, D. R. (2010). Interpersonal influences on adolescent materialism: A new look at the role of parents and peers. Journal of Consumer Psychology, 20(2), 176-184.

Comaroff, J. (2013). Body of power, spirit of resistance: The culture and history of a South African people. University of Chicago Press.

Crocetti, E. (2018). Identity dynamics in adolescence: Processes, antecedents, and consequences. European Journal of Developmental Psychology, 15(1), 11-23.

Croll, J. (2005). Body image and adolescents. Chest (in), 40(35), 50.

Davison, T. E., \& McCabe, M. P. (2006). Adolescent body image and psychosocial functioning. The Journal of Social Psychology, 146(1), 15-30.

Demarest, J., \& Allen, R. (2000). Body image: Gender, ethnic, and age differences. The Journal of Social Psychology, 140(4), 465-472.

Denich, A. U., \& Ifdil, I. (2015). Konsep Body Image Remaja Putri. Jurnal Konseling Dan Pendidikan, 3(2), 5561.

Fortman, T. (2006). The Effects of Body Image on Self-Efficacy, Self Esteem, and Academic Achievement. The Ohio State University.

Gattario, K. H., \& Frisén, A. (2019). From negative to positive body image: Men's and women's journeys from early adolescence to emerging adulthood. Body Image, 28, 53-65.

Gunarsa, S. D. (1991). Psikologi praktis: anak, remaja dan keluarga. BPK Gunung Mulia.

Hubley, A. M., \& Quinlan, L. (2005). Body image across the adult lifespan: it's more gender than age. In 113th annual meeting of the American Psychological Association, Washington DC, August. Available online at http://educ. ubc. ca/faculty/hubley/apa2005/bimage. pdf [Accessed 9 October 2008].

Hurlock, E. B. (1978). Perkembangan anak jilid 2. Jakarta: Erlangga.

Hurlock, E. B. (2001). Developmental psychology. Tata McGraw-Hill Education.

Irvine, K. R., McCarty, K., McKenzie, K. J., Pollet, T. V., Cornelissen, K. K., Toveé, M. J., \& Cornelissen, P. L. (2019). Distorted body image influences body schema in individuals with negative bodily attitudes. Neuropsychologia, 122, 38-50.

MacNeill, L. P., Best, L. A., \& Davis, L. L. (2017). The role of personality in body image dissatisfaction and disordered eating: discrepancies between men and women. Journal of eating disorders, 5(1), 1-9.

Nelson, S. C., Kling, J., Wängqvist, M., Frisén, A., \& Syed, M. (2018). Identity and the body: Trajectories of body esteem from adolescence to emerging adulthood. Developmental Psychology, 54(6), 1159.

Nourmalita, M. (2016). Pengaruh Citra Tubuh terhadap Gejala Body Dismorphic Disorder yang Dimediasi Harga Diri pada Remaja Putri. In Seminar ASEAN 2nd Psychology \& Humanity. Psychology Forum UMM (pp. 546-555).

Orth, U., \& Robins, R. W. (2014). The development of self-esteem. Current directions in psychological science, 23(5), 381-387.

Papalia, D. E., Olds, S. W., \& Feldman, R. D. (2003). Human Development (Vol. ). New York: McGraw-Hill.

Paxton, S. J., \& Damiano, S. R. (2017). The development of body image and weight bias in childhood. Advances in child development and behavior, 52, 269-298.

Perloff, R. M. (2014). Social media effects on young women's body image concerns: Theoretical perspectives and an agenda for research. Sex Roles, 71(11-12), 363-377.

Riaz, R. (2018). The Influence of Culture on Body Image: a thematic analysis investigating perceptions of the effects of cultural appearance ideals on the body image of young women.

Rozin, P., \& Fallon, A. (1988). Body image, attitudes to weight, and misperceptions of figure preferences of the opposite sex: a comparison of men and women in two generations. Journal of Abnormal Psychology, 97(3), 342.

Santrock, J. W. (2007). Perkembangan Anak Jilid 1 Edisi 11. Penerbit Erlangga, Jakarta.

Thompson, J. K., \& Heinberg, L. J. (1999). The media's influence on body image disturbance and eating disorders: We've reviled them, now can we rehabilitate them? Journal of Social Issues, 55(2), 339-353. 
Tylka, T. L. (2018). Body Image: Celebrating the past, appreciating the present, and envisioning the future.

Wertheim, E. H., \& Paxton, S. J. (2011). Body image development in adolescent girls.

Winarni, R. W. (2015). Representasi Kecantikan Perempuan dalam Iklan. Deiksis, 2(2), 134-152.

Yuca, V., \& Handayani, P. G. (2019). Kontribusi Penggunaan Media Massa Terhadap Body Image Mahasiswa Universitas Negeri Padang. Padang.

Yusuf, A. M. (2016). Metode penelitian kuantitatif, kualitatif \& penelitian gabungan. Prenada Media. 